\title{
Introduction To The Workshop On Ecological Effects Of Hydrocarbon Spills In Alaska
}

\author{
R. M. ATLAS ${ }^{1}$ and J. BROWN 1
}

With continued development of Arctic petroleum reserves there has been growing interest in the fate and effects of petroleum hydrocarbons that may be spilled in northern environments. Now that oil is flowing from Prudhoe Bay through the Trans-Alaska Pipeline, there is a pressing need to make known our current knowledge of hydrocarbon research in the Arctic. There have been a number of studies made during the past decade on the ecological effects of hydrocarbon spillages in the Arctic areas lying within the United States, Canada, the Soviet Union, and Scandinavian countries.

Historically, the first major United States Arctic terrestrial and freshwater oil related field research was initiated in summer 1970 at Barrow, Alaska, and on the Cape Simpson seeps. The scientists involved were in the field as part of the United States International Biological Program (IBP) Tundra Biome program. The studies at Barrow involved spills on small ponds and on small soil test plots, and were supported by the United States Army Cold Regions Research Engineering Laboratory (CRREL) and the National Science Foundation (NSF).

Additional experimental spills were initiated at Prudhoe Bay in the early 1970's and on an experimental hot pipeline in Fairbanks. These projects were funded primarily by the oil and gas industry. Industry has supported several projects concerned with recovery of Arctic and subarctic areas following oil spillages.

Research sponsored by the Office of Naval Research (ONR) during this period also examined oil spills in terrestrial and freshwater eco-systems associated with the Arctic Petroleum Reserve No. 4 (redesignated National Petroleum Reserve - Alaska).

In the mid-1970's the United States government initiated an environmental program related to non-renewable energy resources. These energy "pass-through" funds resulted in four 3-year Alaskan projects funded by the Environmental Protection Agency (EPA) and the Energy Resource Development Administration (ERDA). The ERDA sponsored projects, built on the experiments at Barrow, involved: 1) establishing small oil spills across a tundra moisture gradient; and 2) freshwater pond spills. Both began in 1975. The EPA research was to simulate large-scale spills. A controlled spill in a lake along the pipeline near Toolik was undertaken in summer 1976. A

\footnotetext{
'Department of Biology, University of Louisville, Louisville, Kentucky 40208 and U.S. Army Cold Regions Research and Engineering Laboratory, Hanover, New Hampshire 03755
} 
simulated terrestrial winter and summer hot oil spill in interior Alaska was undertaken by CRREL in 1976.

United States Arctic marine studies have been conducted with funds from ONR, the Bureau of Land Management (BLM), and the National Oceanographic Atmospheric Administration (NOAA).

A symposium on "Recovery Potential of Oiled Marine Northern Environments'" was held at Halifax, Nova Scotia in October, 1977. Selected papers from that symposium have been published in a special issue of the Journal of the Fisheries Research Board of Canada (May, 1978). The volume presents in one place current research on oil in cold northern marine Arctic and subarctic ecosystems.

A number of United States investigators felt that a similar meeting was necessary to coordinate results of studies on the fate and effects of hydrocarbons in northern terrestrial and inland aquatic environments. The United States Department of Energy, therefore sponsored a workshop on "Ecological Effects of Hydrocarbon Spills in Alaska," at the Marine Biological Laboratory, Woods Hole, Massachusetts on 8-10 April 1978. Approximately 40 United States investigators who had performed studies on the ecological effects of oil spills in Alaska and four Canadian researchers who had performed related studies in Canada participated in and reviewed manuscripts generated for the workshop. The present volume of Arctic contains papers from this workshop. The papers were organized into aquatic studies (6 papers) and terrestrial studies (12 papers). The Canadian participants summarized the papers, added comments concerning related Canadian and European studies and led provocative discussions concerning past studies and needs for future studies.

United States studies on ecological effects of oil spills in Alaska have been largely field oriented. The general approach in these studies has been to examine experimental, natural, or accidental spillages of petroleum hydrocarbons in situ in Alaskan environments. Figure 1 shows the locations of most of the field sites used in these studies. Several were located at Barrow, Alaska, a site of extensive ecological investigations conducted by the IBP Tundra Biome program. Other sites were located along the Trans-Alaskan Pipeline. These included Prudhoe Bay and several places along the pipeline route where accidental spillages have occurred. Other sites were located in areas of natural seepages or accidental spillages associated with oil exploration activities.

The aquatic studies included papers on the effects of petroleum hydrocarbons on microorganisms, phytoplankton and invertebrates. These concentrated on the ecological effects on lower members of the food web and organisms involved in nutrient cycling. Studies were not reported on the effects of oil on fish, birds, or higher organisms.

Several aquatic and terrestrial papers examined the microbially and abiotically induced changes in petroleum and refined oils spilt in northern ecosystems. The terrestrial papers included reports on the effects of hydrocarbons on vegetation, plant roots, bacteria, fungi, and soil chemical 
parameters. They included reports on vegetation sensitivity to and recovery from burning, and fertilizer application methods aimed at enhancing recovery.

The papers presented here are related to the central theme: ecological effects of oil spills in Alaska. The results of these studies are not readily extrapolated to global predictions on the effects of oil spillages. In general the studies show that: 1) oil from spills will persist for long periods of time in northern eco-systems; 2) that biota of northern ecosystems have varying degrees of tolerance or sensitivity to petroleum hydrocarbons with some populations being decimated by oil spills; 3) other populations flourishing following oil spills; and 4) that recovery, i.e., return to pre-spill conditions will take a prolonged period of time in northern ecosystems following major oil spillages. More needs to be known on the "long term" consequences of northern oil spills and methods for enhancing recovery.

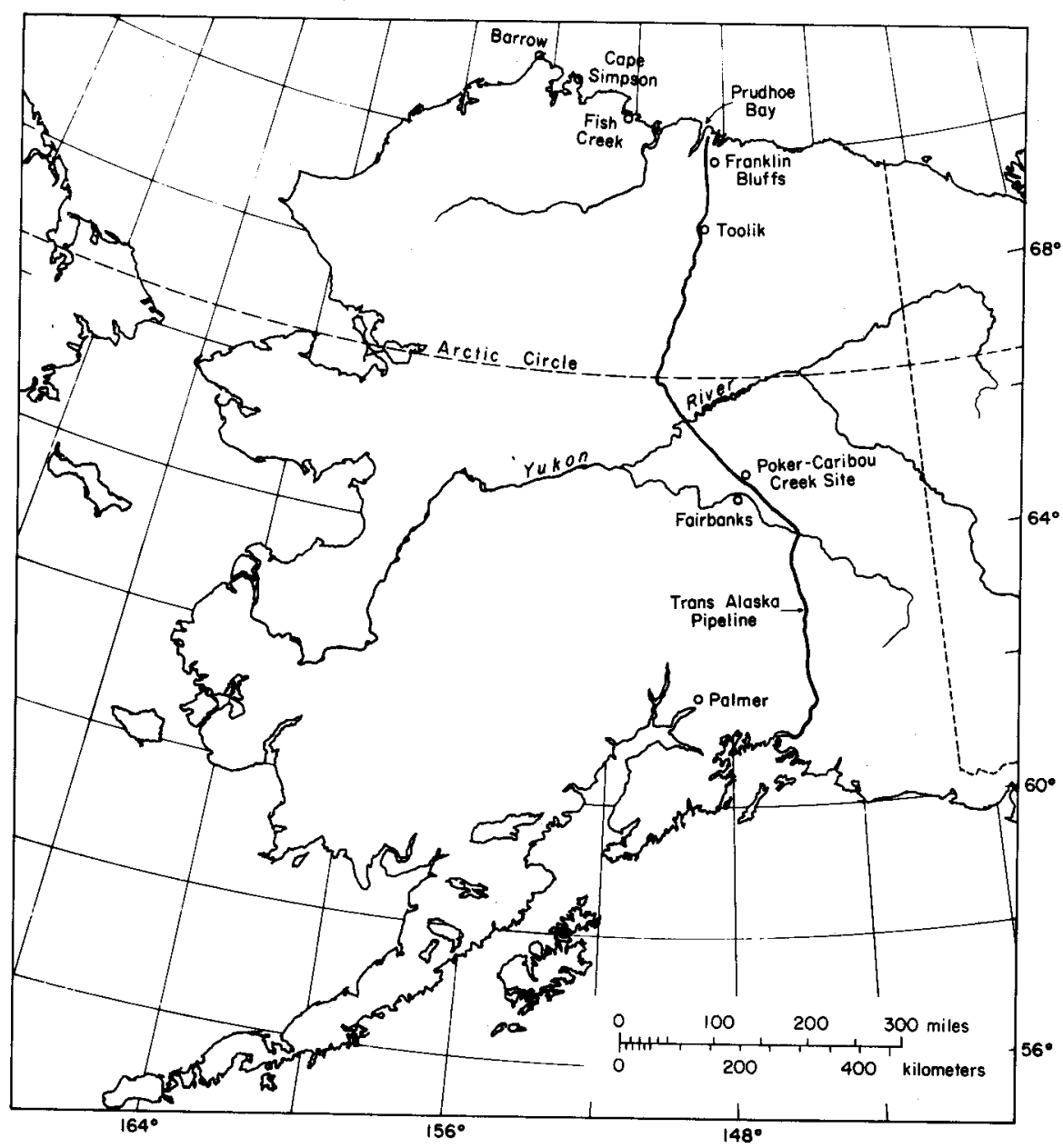

FIG. 1. Map of Alaska showing primary field sites used in these studies. 